\title{
PENGARUH PENEMPATAN DAN LINGKUNGAN KERJA TERHADAP DISIPLIN KERJA SERTA DAMPAKNYA PADA KINERJA PEGAWAI LEMBAGA LAYANAN PENDIDIKAN TINGGI (LLDIKTI) WILAYAH VIII
}

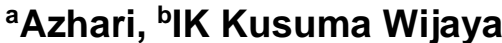 \\ a LLDIKTI WILAYAH VII, ${ }^{b}$ Triatma Mulya University \\ azharikopertis8@yahoo.co.id
}

\begin{abstract}
ABSTRAK
Tujuan penelitian ini adalah menganalisis pengaruh langsung penempatan terhadap disiplin kerja pegawai Lembaga Layanan Pendidikan Tinggi (LLDIKTI) Wilayah VIII. Desain penelitian pada metode penelitian ini termasuk explanatory research, yang menjelaskan hubungan kausal antara variabel-variabel dalam penelitian. Kesimpulannya penempatan berpengaruh positif dan tidak signifikan terhadap disiplin kerja. Hasil ini menunjukkan jika semakin baik penempatan belum tentu akan meningkatkan disiplin kerja pada Lembaga Layanan Pendidikan Tinggi (LLDIKTI) Wilayah VIII. Disiplin kerja pada penelitian ini dipengaruhi oleh penempatan melalui orientasi/pengenalan, kesesuaian minat dengan pekerjan, kesesuaian kemampuan dengan pekerjaan, kesesuaian pengetahuan dengan pekerjaan, dan ilmu yang dimiliki sesuai dengan pekerjaan dapat meningkatkan disiplin kerja dilihat dari aspek mematuhi peraturan perusahaan, bekerja secara efektif, menerima koreksi, hadir selalu tepat waktu dan berusaha menyelesaikan pekerjaan tepat waktu.
\end{abstract}

Kata kunci: Pengaruh Penempatan, Lingkungan Kerja, Disiplin Kerja, Kinerja Pegawai

\section{ABSTRACT}

The purpose of this study was to analyze the direct effect of placement on the work discipline of employees of the Region VIII Higher Education Service Institute (LLDIKTI). The research design in this research method includes explanatory research, which explains the causal relationship between the variables in the study. In conclusion, placement has a positive and insignificant effect on work discipline. These results indicate that if the placement is better it will not necessarily improve work discipline in the Region VIII Higher Education Service Institution (LLDIKTI). Work discipline in this study is influenced by placement through orientation / introduction, suitability of interest to work, suitability of ability to work, suitability of knowledge with work, and knowledge that is in accordance with work can improve work discipline seen from the aspect of complying with company regulations, working effectively, accepting corrections, always being present on time and trying to get work done on time.

Keywords: Effect of Placement, Work Environment, Work Discipline, Employee Performance

\section{PENDAHULUAN}

Manajemen sumber daya manusia diperlukan untuk meningkatkan efektifitas pencapaian tujuan organisasi. Sumber daya manusia didefinisikan sebagai keseluruhan orang-orang dalam organisasi yang memberikan kontribusi terhadap jalannya organisasi. 
Sebagai sumber daya utama organisasi, perhatian penuh terhadap sumber daya manusia harus diberikan terutama dalam kondisi lingkungan yang serba tidak pasti. Selain itu perlu diperhatikan pula bahwa penempatan pegawai yang tepat tidak selalu menyebabkan keberhasilan dan prestasi. Kondisi lingkungan yang cenderung berubah dan perencanaan karir dalam organisasi, mengharuskan organisasi terus-menerus melakukan penyesuaian.

Dalam menjalankan tugas dan kewajibannya, semua pegawai tanpa terkecuali dituntut untuk menghasilkan kinerja yang baik. Kinerja merupakan penampinan hasil karya seseorang dalam bentuk kualitas ataupun kuantitas dalam sutau organisasi. Kinerja dapat merupakan penampilan individu maupun kelompok kerja pegawai.

Salah satu upaya yang dapat menentukan proses prima khususnya dalam organisasi apalagi organisasi pemerintah tergantung pada kinerja. Kinerja pada dasarnya adalah apa yang dilakukan atau tidak dilakukan pegawai yang mana merupakan suatu bentuk atau aplikasi dari target atau hasil kerja yang dicapai. Kinerja pegawai akan mempengaruhi seberapa banyak mereka memberi kontribusi kepada organisasi. Perbaikan kinerja pegawai baik secara individu maupun kelompok, menjadi pusat perhatian dalam upaya meningkatkan kinerja organisasi.

Selain kondisi fisik lingkungan kerja, ternyata lingkungan kerja non fisik di kantor LLDIKTI Wilayah VIII Bali Nusra seperti hubungan antara sesama rekan kerja juga sering menjadi keluhan diantara karyawan. Berdasarkan hasil observasi yang dilakukan dapat diketahui bahwa kerjasama antar sesame rekan kerja di Lembaga tersebut masih belum maksimal. Hal ini terlihat dari masih adanya karyawan yang lebih suka bekerja secara individu daripada harus bekerjasama dengan rekan kerja yang lain. Padahal, kerjasama dalam tim kerja harusnya menjadi sebuah kebutuhan dalam mewujudkan kinerja yang baik, apalagi Lembaga ini harus melayani kebutuhan dari perguruan tinggi yang ada di wilayah Bali Nusra.

Berdasarkan uraian tersebut, maka penulis tertarik untuk melakukan penelitian yang berjudul "Pengaruh Penempatan dan Lingkungan kerja terhadap Disiplin Kerja serta Dampaknya pada Kinerja Pegawai Lembaga Layanan Pendidikan Tinggi (LLDIKTI) Wilayah VIII".

Berdasarkan uraian latar belakang di atas, maka yang menjadi rumusan masalah dalam penelitian ini adalah: (1) Apakah penempatan berpengaruh langsung terhadap disiplin kerja pegawai Lembaga Layanan Pendidikan Tinggi (LLDIKTI) Wilayah VIII?; (2) Apakah lingkungan kerja berpengaruh langsung terhadap disiplin kerja pegawai Lembaga Layanan Pendidikan Tinggi (LLDIKTI) Wilayah VIII?; (3) Apakah penempatan berpengaruh langsung terhadap kinerja pegawai Lembaga Layanan Pendidikan Tinggi (LLDIKTI) Wilayah VIII?; (4) Apakah lingkungan kerja berpengaruh langsung terhadap kinerja pegawai Lembaga Layanan Pendidikan Tinggi (LLDIKTI) Wilayah VIII?; (5) Apakah disiplin kerja berpengaruh langsung terhadap kinerja pegawai Lembaga Layanan Pendidikan Tinggi (LLDIKTI) Wilayah VIII?; (6) Apakah penempatan berpengaruh tak langsung terhadap kinerja pegawai melalui disiplin kerja pegawai Lembaga Layanan Pendidikan Tinggi (LLDIKTI) Wilayah VIII?; (7) Apakah lingkungan kerja berpengaruh tak langsung terhadap kinerja pegawai melalui disiplin kerja pegawai Lembaga Layanan Pendidikan Tinggi (LLDIKTI) Wilayah VIII?

\section{KAJIAN PUSTAKA}

Kajian empiris dalam penelitian ini dilandasi oleh kajian empiris yang sudah dilakukan sebelumnya. Penelitian yang sejenis terkait dengan objek yang diteliti menjadi referensi dan landasan dalam penulisan ini yaitu menyangkut masalah penempatan, lingkungan kerja, disiplin kerja dan kinerja pegawai, walaupun dengan penekanan dan fokus yang berbeda.

Penelitian oleh Isyani Nur pada tahun 2013 yang berjudul Pengaruh Penempatan Pegawai terhadap Disiplin Kerja di Badan Kepegawaian Daerah Pemerintah Provinsi Jawa Barat. Hasil analisis menunjukkan bahwa terdapat pengaruh positif penempatan pegawai terhadap disiplin kerja pada Badan Kepegawaian Daerah Pemerintah Provinsi Jawa Barat. 
Hal tersebut menunjukkan penempatan pegawai yang sesuai akan dapat meningkatkan disiplin kerja pegawai.

Penelitian dari Dewi Andriani pada tahun 2010 dengan judul Pengaruh Lingkungan Kerja terhadap Disiplin Kerja Karyawan PT. Hassco Multi Kimindo Sidoarjo. Hasil analisis menunjukkan bahwa lingkungan kerja berpengaruh positif terhadap disiplin kerja karyawan PT. Hassco Multi Kimindo Sidoarjo. Hal tersebut menunjukkan bahwa lingkungan kerja yang baik dan kondusif akan meningkatkan disiplin kerja karyawan.

Penelitian dari Rifaldi Dwi Putra pada tahun 2016 dengan judul Pengaruh Penempatan Pegawai dan Lingkungan Kerja terhadap Kinerja Pegawai di Koperasi Pegawai Pemerintah Kota Bandung (KPKB). Hasil analisis menunjukkan terdapat pengaruh positif dan signifikan penempatan dan lingkungan kerja baik secara parsial maupun simultan terhadap kinerja pegawai pada Koperasi Pegawai Pemerintah Kota Bandung.

Penelitian dari Prastika Meilany dan Mariaty Ibrahim pada tahun 2015 dengan judul Pengaruh Disiplin Kerja terhadap Kinerja Karyawan (Kasus Bagian Operasional PT. Indah Logistik Cargo Cabang Pekanbaru). Hasil analisis menunjukkan bahwa disiplin kerja berpengaruh positif dan signifikan terhadap kinerja karyawan. Hal ini menunjukkan semakin baik disiplin kerja maka kinerja karyawan bagian operasional pada PT. Indah Logistik Cargo Cabang Pekanbaru akan semakin baik pula.

Para karyawan yang telah seleksi menjalankan program orientasi harus segera mendapatkan pekerjaan yang sesuai dengan bakat dan keahlian yang dimilikinya. Hasibuan (2012:70) menyatakan bahwa penempatan (placement) karyawan adalah tindak lanjut dari seleksi yaitu menempatkan calon karyawan yang diterima (lulus seleksi) pada jabatan/pekerjaan yang membutuhkan dan sekaligus mendelegasikan authority kepada orang tersebut, dengan demikian calon karyawan itu akan dapat mengerjakan tugastugasnya dijabatan bersangkutan. Pengertian penempatan menurut Hariandja (2009:156) adalah proses penugasan atau pengisian jabatan atau penugasan kembali pegawai pada tugas atau jabatan baru atau jabatan yang berbeda.

\section{Jenis-jenis Penempatan}

Terdapat tiga jenis penempatan menurut Ardana (2012:90) yaitu promosi, transfer, dan demosi. Berikut ini dijelaskan tiga jenis penempatan tersebut (1) Promosi; (2) Transfer; (3) Demosi.

\section{Tujuan Penempatan}

Penempatan tidak hanya berfokus bagi karyawan baru, namun juga bagi karyawan lama yang mengalami alih tangan dan mutasi. Menurut Hariandja (2009:159) yang menjadi tujuan proses penempatan sumber daya manusia adalah sebagai berikut: (1) Mengisi formasi atau lowongan yang tersedia dalam perusahaan. (2) SDM yang baru lulus tidak terlalu lama menunggu diangkat dan apa yang akan dikerjakan. (3) Menempatkan orang yang tepat ada posisi yang tepat. (4)Agar perusahaan dapat bekerja efisien dengan memanfaatkan SDM yang tepat tersebut.

\section{Pengertian Lingkungan Kerja}

Manajemen yang baik adalah memikirkan bagaimana tentang lingkungan kerja yang baik dan menyengkan, karena sangat dibutuhkan oleh tenaga kerjanya. Lingkungan kerja diduga mempunyai pengaruh kuat dalam pembentukan prilaku karyawan. Secara umum lingkungan kerja dalam suatu organisai atau perusahaan dimana keryawan melaksanakan tugas dan pekerjaannya. Menurut Nitisemito (dalam Sugiarti, 2012) lingkungan kerja adalah segala sesuatu yang ada di lingkungan pekerja yang dapat mempengaruhi dirinya dalam menjalankan tugas yang dibebankan.

\section{Arti Penting Lingkungan Kerja}

Lingkungan kerja penting mendapat perhatian dari perusahaan karena dilihat dari peranannya lingkungan kerja merupakan salah satu faktor yang mempunyai pengaruh yang cukup besar terhadap sumber daya manusia dalam suatu perusahaan. Menurut Scholder 
dan Jakson (dalam Sugiarti, 2012) bahwa lingkungan kerja yang aman dapat membuat para pekerja menjadi sehat dan produktif dalam melaksanakan pekerjaannya.

\section{Indikator-Indikator Lingkungan Kerja}

Lingkungan kerja merupakan kondisi fisik dalam perusahaan yang dapat dipersiapkan oleh manajemen perusahaan, yang meliputi penerangan (sinar) yang cukup, suhu udara yang tepat, suara bising yang dapat dikendalikan, penggunaan warna, ruang gerak yang diperlukan serta keamanan kerja karyawan, beberapa faktor yang dapat menentukan terbentuknya suatu kondisi lingkungan kerja dikaitkan dengan produktivitas kerja karyawan (Sedarmayanti, 2011).

\section{Pengertian Disiplin Kerja}

Menurut Mangkunegara (2011) disiplin kerja diartikan sebagai pelaksanaan manajemen untuk memperteguh pedoman-pedoman organisasi. Sedangkan menurut Hasibuan (2012), kedisiplinan adalah kunci keberhasilan suatu perusahaan dalam mencapai tujuannya.

\section{Jenis-jenis Disiplin Kerja}

Gorda (2012:107) mengemukakan bahwa disiplin dibedakan menjadi dua yaitu: Disiplin preventif, Disiplin korektif.

\section{Faktor-faktor yang Mempengaruhi Disiplin Kerja}

Menurut Hasibuan (2012:195) faktor yang mempengaruhi disiplin kerja pegawai adalah: Tujuan dan kemampuan, Teladan pemimpin, Balas Jasa, Keadilan, Pengawasan melekat, Sanksi hukuman, Ketegasan, Hubungan kemanusiaan.

\section{Indikator-indikator Disiplin Kerja}

Indikator-indikator disiplin kerja menurut Simamora (2011) adalah sebagai berikut: Kepatuhan pada peraturan, Efektif dalam bekerja, Tindakan korektif, Kehadiran tepat waktu, Menyelesaikan pekerjaan tepat waktu.

\section{Pengertian Kinerja Pegawai}

Perilaku yang nyata yang ditampilkan setiap orang sebagai prestasi kerja yang dihasilkan oleh pegawai sesuai dengan perannya dalam perusahaan (Rivai, 2014). Sedangkan Robbins mendefinisikan kinerja adalah suatu ukuran yang mencakup keefektifan dalam pencapaian tujuan dan efisiensi yang merupakan rasio dari keluaran efektif terhadap masukan yang diperlukan untuk mencapai tujuan itu.

\section{Faktor-faktor Kinerja Pegawai}

Faktor yang mempengaruhi pencapaian kinerja adalah kemampuan (ability) dan faktor lingkungan kerja (motivation). Hal ini sesuai dengan pendapat Davis yang dikutip oleh Mangkunegara (2011) yang merumuskan faktor-faktor yang membentuk kinerja (Human performance)

\section{Penilaian Kinerja Pegawai}

Penilaian kinerja merupakan prosedur yang sistematik meliputi penetapan standar kinerja, mengandalkan penilaian atas dasar yang telah ditetapkan dan selanjutnya memberikan umpan balik kepada pegawai yang dinilai dengan harapan dapat bermanfaat sebagai lingkungan kerja bagi pegawai untuk memberi sumbangan yang lebih baik (Gorda, 2012).

\section{Indikator-indikator Kinerja Pegawai}

Robbins (2016) menyatakan indikator untuk mengukur kinerja pegawai secara individu ada 6 indikator yaitu: Kualitas, Kuantitas, Ketepatan waktu, Efektivitas, Kemandirian, Komitmen kerja. 


\section{METODOLOGI PENELITIAN}

\section{Desain Penelitian}

Penelitian ini termasuk explanatory research, yang akan menjelaskan hubungan kausal antara variabel-variabel dalam penelitian.

\section{Populasi dan Penentuan Sampel Penelitian}

Sebelum penarikan sampel dilakukan, terlebih dahulu ditentukan populasi yang dimaksud dalam hal ini adalah jumlah seluruh pegawai di Lembaga Layanan Pendidikan Tinggi (LLDIKTI) Wilayah VIII sebanyak 58 orang, akan diambil sampel keseluruhan pegawai sebanyak 58 orang. Hal ini sesuai dengan pendapat Arikunto (2012) bahwa: "Apabila subyek kurang dari 100 lebih baik diambil semua, sehingga penelitian merupakan penelitian populasi. Selanjutnya jika subyek lebih besar dari 100 dapat diambil antar 10$15 \%$ atau $20-25 \%$ atau lebih".

\section{Instrumen Penelitian}

Adapun instrumen-instrumen untuk variabel penempatan (X1), lingkungan kerja (X2), disiplin kerja (Y1) dan kinerja pegawai (Y2).

\section{Jenis dan Sumber Data}

Adapun jenis data yang digunakan dalam penelitian ini adalah Data Kuantitatif dan Data Kualitatif. Sumber data adalah data primer dan data sekunder.

\section{Metode Pengumpulan Data}

Metode pengumpulan data yang digunakan dalam penelitian ini adalah Observasi, Wawancara, Dokumentasi, Kuesioner. Teknik pengumpulan data dengan mempergunakan daftar pertanyaan yang tertulis yang disebarkan kepada responden, untuk dimintai keterangan terhadap sesuatu yang berhubungan dengan masalah yang dibahas dalam penelitian ini.

\section{HASIL PENELITIAN DAN PEMBAHASAN}

\section{Hasil Pengujian Hipotesis}

Pengujian hipotesis dilakukan dengan t-test pada masing-masing jalur pengaruh langsung secara parsial dan pengaruh tak langsung melalui variabel mediasi. Terkait dengan pengujian ini maka pengujian hipotesis dapat dipilah menjadi pengujian pengaruh langsung dan pengujian pengaruh tak langsung atau pengujian variabel mediasi. Pada bagian berikut ini diuraikan secara berturut-turut hasil pengujian pengaruh langsung dan pengujian variabel mediasi.

1. Pengujian Pengaruh Langsung

Hasil uji validasi koefisien path pada setiap jalur untuk pengaruh langsung dan efek dapat disajikan pada tabel 1 berikut ini.

Tabel 1

Hasil Pengujian Hipotesis Pengaruh Langsung dan Pengaruh Tanpa Variabel Mediasi

\begin{tabular}{|lll||c||c||}
\hline \hline \multicolumn{2}{|l||}{ Hubungan Antar Variabel } & $\begin{array}{c}\text { Original sample } \\
\text { estimate }\end{array}$ & $\begin{array}{c}\text { T- } \\
\text { Statistic }\end{array}$ & Keterangan \\
\hline $\begin{array}{l}\text { Penempatan } \\
\text { Kerja }\left(\mathrm{Y}_{1}\right)\end{array}$ & $->\quad$ Disiplin & 0.229 & 1.477 & Tidak Signifikan \\
\hline $\begin{array}{l}\text { Lingkungan kerja } \\
\text { Disiplin Kerja }\left(\mathrm{Y}_{1}\right)\end{array}$ & $\left(\mathrm{X}_{2}\right) \quad->$ & 0.306 & 1.638 & Tidak Signifikan \\
\hline $\begin{array}{l}\text { Penempatan } \\
\text { Pegawai }\left(\mathrm{Y}_{2}\right)\end{array}$ & $->\quad$ Kinerja & 0.099 & 0.706 & Tidak Signifikan \\
\hline
\end{tabular}




\begin{tabular}{|c|c|c|c|}
\hline $\begin{array}{l}\text { Lingkungan kerja }\left(\mathrm{X}_{2}\right)->\text { Kinerja } \\
\text { Pegawai }\left(\mathrm{Y}_{2}\right)\end{array}$ & -0.060 & 0.410 & Tidak Signifikan \\
\hline $\begin{array}{l}\text { Disiplin Kerja }\left(\mathrm{Y}_{1}\right) \quad \rightarrow \text { Kinerja } \\
\text { Pegawai }\left(\mathrm{Y}_{2}\right)\end{array}$ & 0.730 & 7.153 & Signifikan \\
\hline \multicolumn{4}{|c|}{$\begin{array}{c}\text { Pengujian Disiplin Kerja }\left(\mathrm{Y}_{1}\right) \text { sebagai Variabel Mediasi (Model Tanpa Variabel } \\
\text { Mediasi }\end{array}$} \\
\hline $\begin{array}{llll}\text { Penempatan } & \left(\mathrm{X}_{1}\right) & \rightarrow & \text { Kinerja } \\
\text { Pegawai }\left(\mathrm{Y}_{2}\right) & & \end{array}$ & 0.281 & 1.887 & Tidak Signifikan \\
\hline $\begin{array}{l}\text { Lingkungan kerja }\left(\mathrm{X}_{2}\right)->\text { Kinerja } \\
\text { Pegawai }\left(\mathrm{Y}_{2}\right)\end{array}$ & 0.165 & 0.947 & Tidak Signifikan \\
\hline
\end{tabular}

Sumber : data diolah, 2020

2. Pengujian Pengaruh Tak Langsung Melalui Variabel Mediasi

Dalam pengujian hipotesis, berikut ini akan dikaji peran mediasi variabel disiplin kerja $\left(Y_{1}\right)$ pada pengaruh tak langsung penempatan $\left(X_{1}\right)$ dan lingkungan kerja $\left(X_{2}\right)$ terhadap kinerja pegawai $\left(\mathrm{Y}_{2}\right)$. Adapun pengujian hipotesis pengaruh tak langsung dalam penelitian ini dapat dipaparkan hasil analisisnya dalam tabel 2 berikut ini :

Tabel 2

Rekapitulasi Hasil Pengujian Variabel Non Mediasi

\begin{tabular}{|c|c|c|c|c|c|c|}
\hline \multirow{2}{*}{ No } & \multirow{2}{*}{$\begin{array}{c}\text { Mediasi Variabel Disiplin } \\
\text { Kerja pada: }\end{array}$} & \multicolumn{4}{|c|}{ Efek } & \multirow{2}{*}{ Keterangan } \\
\hline & & (A) & (B) & (C) & (D) & \\
\hline 1 & $\begin{array}{l}\text { Penempatan }\left(\mathrm{X}_{1}\right)-> \\
\text { Kinerja Pegawai }\left(\mathrm{Y}_{2}\right)\end{array}$ & $\begin{array}{l}0,092 \\
\text { (Non } \\
\text { Sig.) }\end{array}$ & $\begin{array}{l}0,255 \\
\text { (Non } \\
\text { Sig.) }\end{array}$ & $\begin{array}{l}0,241 \\
\text { (Non } \\
\text { Sig.) }\end{array}$ & $\begin{array}{l}0,726 \\
\text { (Sig.) }\end{array}$ & Non Mediasi \\
\hline 2 & $\begin{array}{c}\text { Lingkungan kerja }\left(\mathrm{X}_{2}\right)-> \\
\text { Kinerja Pegawai }\left(\mathrm{Y}_{2}\right)\end{array}$ & $\begin{array}{l}-0,029 \\
\text { (Non } \\
\text { Siq.) }\end{array}$ & $\begin{array}{l}0,251 \\
\text { (Non } \\
\text { Sig.) }\end{array}$ & $\begin{array}{l}0,354 \\
\text { (Non } \\
\text { Sig.) }\end{array}$ & $\begin{array}{l}0,726 \\
\text { (Sig.) }\end{array}$ & Non Mediasi \\
\hline \multicolumn{7}{|c|}{ Kalkulasi Efek Langsung, Tak Langsung dan Total } \\
\hline No & Hubungan Variabel & \multicolumn{2}{|c|}{ Efek Langsung } & \multicolumn{2}{|c|}{$\begin{array}{c}\text { Efek Tak } \\
\text { Langsung }\end{array}$} & Efek Total \\
\hline 1 & $\begin{array}{lll}\text { Penempatan } & \left(\mathrm{X}_{1}\right) & -> \\
\text { Disiplin Kerja }\left(\mathrm{Y}_{1}\right) & -> \\
\text { Kinerja Pegawai }\left(\mathrm{Y}_{2}\right) & \end{array}$ & \multicolumn{2}{|c|}{0,092} & \multicolumn{2}{|c|}{$\begin{array}{c}0,174 \\
\left(0,241^{*} 0,726\right)\end{array}$} & 0,266 \\
\hline 2 & 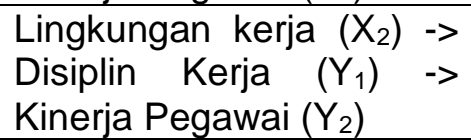 & \multicolumn{2}{|c|}{$-0,029$} & \multicolumn{2}{|c|}{$\begin{array}{c}0,257 \\
\left(0,354^{*} 0,726\right)\end{array}$} & 0,228 \\
\hline
\end{tabular}

Keterangan: Signifikan (Sig.) $=$ T-Statistic $>.1,96$ pada $\alpha: 5 \%$

Sumber : data diolah, 2020

Berdasarkan hasil pengujian hipotesis-hipotesis yang telah diuraikan di atas, maka disusun diagram jalur seperti pada Gambar 1 berikut ini. 


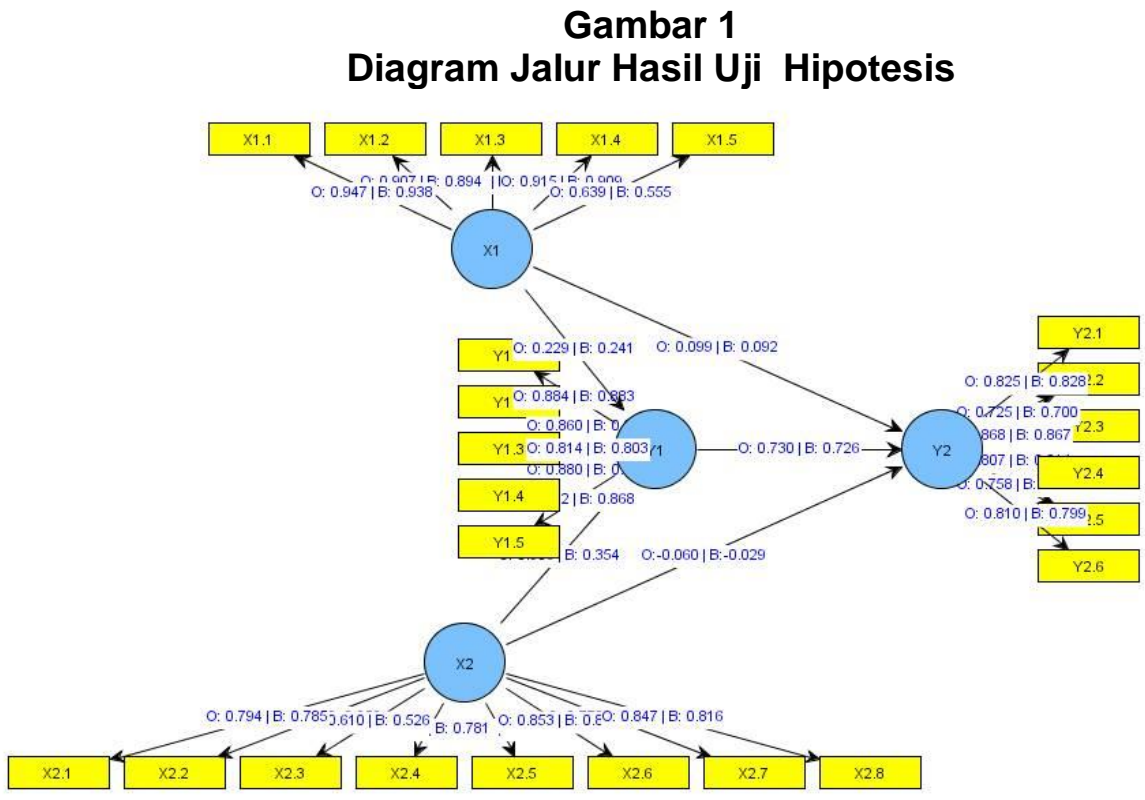

Sumber : data diolah, 2020

\section{Profil Variabel Penelitian}

Kajian ini dilakukan untuk mendalami variabel-variabel yang diteliti berdasarkan nilai bobot faktor (factor loading) dan rerata (mean). Adapun sajian profil variabel penempatan $\left(\mathrm{X}_{1}\right)$, lingkungan kerja $\left(\mathrm{X}_{2}\right)$, disiplin kerja $\left(\mathrm{Y}_{1}\right)$ dan kinerja pegawai $\left(\mathrm{Y}_{2}\right)$ dapat dipaparkan sebagai berikut:

1. Profil Penempatan

Penempatan adalah merupakan suatu proses penempatan pegawai pada bidang kerja pada Lembaga Layanan Pendidikan Tinggi (LLDIKTI) Wilayah VIII. Profil penempatan ini tersaji pada tabel 3 berikut ini.

Tabel 3

Bobot Faktor dan Rerata Variabel Penempatan

\begin{tabular}{|l|c|c|c|}
\hline \multirow{2}{*}{ Indikator/Item } & \multicolumn{2}{c|}{ Bobot Faktor } & \multirow{2}{*}{ Rerata } \\
\cline { 2 - 3 } & Out Loading & T-Satistic & \\
\hline Orientasi/Pengenalan & $\mathbf{0 . 9 3 8}$ & $\mathbf{3 3 . 3 9 6}$ & $\mathbf{3 . 9 8 2 8}$ \\
\hline $\begin{array}{l}\text { Kesesuaian minat dengan } \\
\text { pekerjaan }\end{array}$ & 0.894 & 20.071 & 3.9828 \\
\hline $\begin{array}{l}\text { Kesesuaian kemampuan } \\
\text { dengan pekerjaan }\end{array}$ & 0.899 & 20.987 & 3.9138 \\
\hline $\begin{array}{l}\text { Kesesuaian pengetahuan } \\
\text { dengan pekerjaan }\end{array}$ & 0.909 & 26.584 & 3.8966 \\
\hline $\begin{array}{l}\text { Ilmu yang dimiliki sesuai dengan } \\
\text { pekerjaan }\end{array}$ & 0.555 & 2.886 & $\mathbf{4 . 1 2 0 7}$ \\
\hline
\end{tabular}

Sumber : data diolah, 2020

2. Profil Lingkungan kerja

Lingkungan kerja merupakan segala sesuatu yang ada di sekitar pegawai untuk medorong pegawai bekerja lebih baik, dan merupakan suatu alat bagi pegawai untuk meningkatkan kinerjanya. Adapun profil lingkungan kerja yang dimaksud terdapat pada tabel 4 berikut ini: 
Tabel 4

Bobot Faktor dan Rerata Variabel Lingkungan kerja

\begin{tabular}{|l|c|c|c|}
\hline \multirow{2}{*}{\multicolumn{1}{|c|}{ Indikator/Item }} & \multicolumn{2}{c|}{ Bobot Faktor } & \multirow{2}{*}{ Rerata } \\
\cline { 2 - 3 } & Out Loading & T-Satistic & \\
\hline Penerangan & 0.785 & 11.533 & 3.7414 \\
\hline Suhu Udara & $\mathbf{0 . 8 5 8}$ & $\mathbf{1 2 . 6 5 8}$ & $\mathbf{4 . 1 0 3 4}$ \\
\hline Penyusunan warna & 0.526 & 2.429 & 4.1897 \\
\hline Ruang gerak & 0.781 & 8.026 & $\mathbf{4 . 2 5 8 6}$ \\
\hline Suhu dalam ruang kerja & 0.818 & 10.417 & 4.2414 \\
\hline Kebersihan & 0.823 & 9.968 & 4.0862 \\
\hline Keamanan & 0.752 & 9.223 & 4.0862 \\
\hline Hubungan dengan rekan kerja & 0.816 & 10.230 & $\mathbf{4 . 2 5 8 6}$ \\
\hline
\end{tabular}

Sumber : data diolah, 2020

3. Profil Disiplin Kerja

Disiplin kerja merupakan sikap kerja pegawai untuk selalu berusaha bekerja sesuai dengan aturan-aturan yang berlaku dengan tidak melanggar aturan-aturan yang sudah ditetapkan. Profil disiplin kerja dapat disajikan pada tabel 5 berikut ini :

Tabel 5

Bobot Faktor dan Rerata Variabel Disiplin Kerja

\begin{tabular}{|l|c|c|c|}
\hline \multirow{2}{*}{\multicolumn{1}{|c|}{ Indikator/Item }} & \multicolumn{2}{c|}{ Bobot Faktor } & \multirow{2}{*}{ Rerata } \\
\cline { 2 - 3 } & Out Loading & T-Satistic & \\
\hline $\begin{array}{l}\text { Mematuhi peraturan } \\
\text { perusahaan }\end{array}$ & 0.883 & 22.935 & 4.2759 \\
\hline Bekerja secara efektif & 0.854 & 16.119 & 4.2586 \\
\hline Menerima koreksi & 0.803 & 10.263 & 4.2414 \\
\hline Hadir selalu tepat waktu & $\mathbf{0 . 8 8 5}$ & $\mathbf{3 0 . 2 8 5}$ & $\mathbf{4 . 3 1 0 3}$ \\
\hline $\begin{array}{l}\text { Berusaha menyelesaikan } \\
\text { pekerjaan tepat waktu }\end{array}$ & 0.868 & 20.228 & 4.2241 \\
\hline
\end{tabular}

Sumber : data diolah, 2020

4. Profil Kinerja Pegawai

Kinerja pegawai merupakan hasil kerja yang dicapai pegawai Lembaga Layanan Pendidikan Tinggi (LLDIKTI) Wilayah VIII dari tugas dan pekerjaan yang diberikan. Profil kinerja pegawai tersaji pada tabel 6 dibawah ini:

Tabel 6

Bobot Faktor dan Rerata Variabel Kinerja Pegawai

\begin{tabular}{|l|c|c|c|}
\hline \multirow{2}{*}{ Indikator/Item } & \multicolumn{2}{c|}{ Bobot Faktor } & \multirow{2}{*}{ Rerata } \\
\cline { 2 - 3 } & Out Loading & T-Satistic & 4.2414 \\
\hline Kualitas kerja sesuai standar & 0.828 & 15.822 & 4.1724 \\
\hline $\begin{array}{l}\text { Hasil kerja sesuai kuantitas } \\
\text { kerja }\end{array}$ & 0.700 & 5.981 & $\mathbf{4 . 2 2 4 1}$ \\
\hline $\begin{array}{l}\text { Kemampuan menyelesaikan } \\
\text { pekerjaan tepat waktu }\end{array}$ & $\mathbf{0 . 8 6 7}$ & $\mathbf{2 1 . 2 6 7}$ & 4.1552 \\
\hline $\begin{array}{l}\text { Penyelesaian pekerjaan dengan } \\
\text { efektif }\end{array}$ & 0.814 & 14.523 & 4.1897 \\
\hline Menyelesaikan pekerjaan & 0.738 & 7.000 & \\
\hline
\end{tabular}


dengan mandiri

Memiliki komitmen kerja
0.799

11.510

Sumber : data diolah, 2020

Tabel diatas memberikan informasi bahwa kemampuan menyelesaikan pekerjaan tepat waktu memiliki bobot faktor tertinggi yaitu sebesar 0.867 sedangkan indikator hasil kerja sesuai kualitas kerja memperoleh bobot faktor terendah sebesar 0,700 . Temuan ini menunjukkan bahwa hasil utama yang harus dicapai oleh pegawai Lembaga Layanan Pendidikan Tinggi (LLDIKTI) Wilayah VIII adalah mampu menyelesaikan pekerjaan tepat waktu. Namun kenyataannya pegawai pada Lembaga Layanan Pendidikan Tinggi (LLDIKTI) Wilayah VIII memandang bahwa memiliki komitmen kerja sebagai ukuran dalam mencapai kinerjanya mendapat tanggapan tertinggi yaitu 4,3448.

\section{KESIMPULAN DAN SARAN}

Kesimpulannya penempatan berpengaruh positif dan tidak signifikan terhadap disiplin kerja. Hasil ini menunjukkan jika semakin baik penempatan belum tentu akan meningkatkan disiplin kerja pada Lembaga Layanan Pendidikan Tinggi (LLDIKTI) Wilayah VIII.

\section{REFERENSI}

Alfian Ahmad. 2018. Pengaruh Penempatan Kerja Pegawai terhadap Disiplin Kerja di Kantor Camat Bulango Timur Kabupaten Bone Bolango. Skripsi.

Ardana, dkk. 2012. Manajemen Sumber Daya Manusia. Yogyakarta: Graha IImu.

Arikunto, Suharsini. 2012. Prosedur Penelitian, Suatu Pendekatan Produk, Edisi Revisi V. Jakarta: PT. Rineka Cipta.

Dewi Andriani. 2010. Pengaruh Lingkungan Kerja terhadap Disiplin Kerja Karyawan PT. Hassco Multi Kimindo Sidoarjo. Jurnal Aplikasi Manajemen, Vol. 8 No. 4 Nopember 2018.

Fariz Ramanda Putra. 2013. Pengaruh Lingkungan Kerja terhadap Kinerja (Studi pada Karyawan PT. Naraya Telematika Malang). Jurnal Administrasi Bisnis (JAB), Vol. 6, No. 1 April 2013.

Ghozali, Imam. 2015. Partial Least Squares Konsep, Teknik dan Aplikasi Menggunakan Program SmartPLS 3.0 Untuk Penelitian Empiris. Edisi 2. Semarang: Badan Penerbit Universitas Diponogoro.

Ghozali, Imam. 2016. Aplikasi Analisis Multifariate dengan Program SPSS. Edisi Kedua. Semarang: Badan Penerbit Universitas Diponogoro.

Gorda, I Gusti Ngurah. 2012. Manajemen Sumber Daya Manusia. Edisi Revisi. Denpasar : Astabrata

Hariandja, Marihot Tua Efendi. 2009. Manajemen Sumber Daya Manusia. Jakarta: PT. Grasindo

Hasibuan, Malayu S.P. 2012. Manajemen Sumber Daya Manusia. Jakarta : $\quad$ PT. Bumi Aksara.

Isyani Nur. 2013. Pengaruh Penempatan Pegawai terhadap Disiplin Kerja di Badan Kepegawaian Daerah Pemerintah Provinsi Jawa Barat. Skripsi. Universitas Pendidikan Indonesia.

Mangkunegara, Anwar Prabu. 2011. Manajemen Sumber Daya Perusahaan. Bandung: PT. Remaja Rosdakarya.

Prastika Meilany dan Mariaty Ibrahim. 2015. Pengaruh Disiplin Kerja terhadap Kinerja Karyawan (Kasus Bagian Operasional PT. Indah Logistik Cargo Cabang Pekanbaru). JOM Fisip, Vol. 2 No. 2 Oktober 2015.

Rifaldi Dwi Putra. 2016. Pengaruh Penempatan Pegawai dan Lingkungan Kerja terhadap Kinerja Pegawai di Koperasi Pegawai Pemerintah Kota Bandung (KPKB). Skripsi. Universitas Pasundan Bandung. 
Rivai, Veithzal. 2014. Manajemen Sumber Daya Manusia untuk Perusahaan. Jakarta: PT. Raja Grafindo Persada.

Robbins \& Judge. 2012. Perilaku Organisasi, Edisi 12. Jakarta: Salemba Empat

Ruliana, dkk. 2015. Pengaruh Penempatan dan Lingkungan Kerja terhadap Disiplin Kerja dan Kinerja Pegawai pada Dinas Perkebunan Provinsi Banten. Tesis.

Sedarmayanti. 2011. Manajemen Sumbar Daya Manusia, Reformasi, Birokrasi dan Manajemen Pegawai Negeri Sipil, Cetakan Kelima. Bandung: PT. Refika Aditama.

Simamora, Hendry. 2011. Manajemen Sumber Daya Manusia. Cetakan Kedua. Edisi Ketiga. Yogyakarta : STIE YKPN

Stewart, C.J., \& Cash, William B. 2012. Interviu: Prinsip dan Praktik Edisi 13. Jakarta : Salemba Humanika.

Sugiarti, Gita. 2012. Pengaruh Lingkungan Kerja, Budaya Organisasi dan Kompensasi terhadap Kepuasan Kerja untuk Meningkatkan Kinerja Pegawai (Studi pada Fakultas Ekonomi Universitas 17 Agustus 1945 Semarang. E-Jurnal Serat Acitya, Vol. 1 No. 2 Tahun 2012.

Sugiyono. 2012. Metode Penelitian Kuantitatif, Kualitatif, dan R\&D. Bandung: CV Alfabeta Suwanto \& Priansa, Donni Juni.2011. Manajemen SDM Dalam Organisasi Publik dan Bisnis. Bandung: Alfabeta.

Wirawan 2012. Evaluasi Kinerja Sumber Daya Manusia, Teori, Aplikasi dan Penelitian, Jakarta: Salemba Empat

Yovita Aldilaningsari, dkk. 2014. Pengaruh Penempatan Kerja terhadap Kinerja (Studi pada Karyawan PT. Bank Jatim Cabang Malang). Jurnal Administrasi Bisnis (JAB), Vol. 9 No. 1 April 2014. 